\title{
The market reaction to profitability: Does leverage matter?
}

\section{Tawfiq Abdel-Jalil ${ }^{a}$, Ahmad Daher ${ }^{a}$, Ghaleb Abu Rumman ${ }^{a^{*}}$ and Ahmad Bsoul ${ }^{b}$}

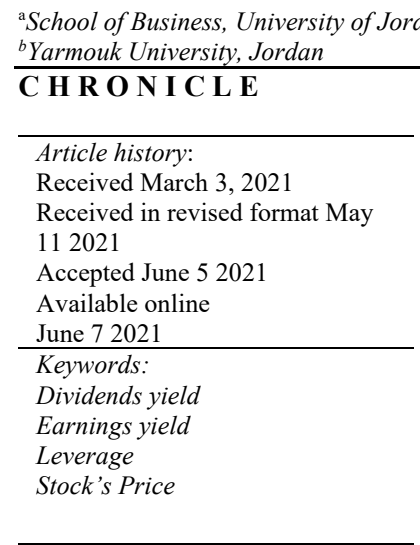

\begin{abstract}
A B S T R A C T
This study examined the market reaction to profitability by discussing the impact of dividends yield (DY) and earnings yield (EY) based on leverage (LVRG), as a control variable, on stocks' prices (SP) of the industrial companies listed on Amman Stock Exchange (ASE), for the whole sample and the two subsamples (low and high leveraged companies). For this purpose, the data of the three samples were analyzed, for seven years from 2011 to 2017. The multiple regression analysis results showed that based on the leverage ratio (LVRG), as a control variable, there is a significant effect of DY on SP at 1\% significance level, and an insignificant effect of EY on SP at 5\% significance level, in the high leveraged sample. The impact of DY and EY on SP at $5 \%$ significance level in the whole and low leveraged samples is insignificant.
\end{abstract}

(C) 2022 Growing Science Ltd. All rights reserved.

\section{Introduction}

Management and Investors evaluate the company's value and performance through stock's price. The change in Stock's price is considered as an important indicator of management policy and efficiency. Earnings and Dividends affect a stock's price (Ang \& Ciccone, 2011). High earnings levels usually increase a stock's price and vice versa, while the effect of dividends on a stock's price depends on the investor's risk level. Dividend yields are the amount that the company decides to pay. When an investor buys a stock, he is buying the future cash flow potential of a company, and earnings yield is one way to measure at least the current valuation to income. Despite the advantage of existing tax savings from debt financing (financial leverage), depending on borrowed funds without its efficient use will expose company owners to risks, causing them to claim a higher level of return required. Companies pay dividends to distribute profits to shareholders, and which also signals corporate health and earnings growth to investors. Because shares prices represent future cash flows, future dividend streams are incorporated into the share price, and discounted dividend models can help analyze a stock's value. For investors, dividends serve as a popular source of investment income. For the issuing company, they are a way to redistribute profits to shareholders to thank them for their support and to encourage additional investment. Dividends also serve as an announcement of the company's success. Because dividends are issued from a company's retained earnings only companies that are substantially profitable issue dividends with any consistency (Bureau of Economic Analysis). Graham and Dodd (1951) pointed out that: The dividend return is the overshadowing factor in common-stock investment. This point of view is based on simple logic. The prime purpose of a business corporation is to pay dividends to its owners. A successful company is one that can pay dividends regularly and presumably increase the rate as time goes on. Since the idea of investment is closely bound up with that of dependable income, it follows that investing in common stocks would ordinarily be confined to those with a well-established dividend. It would also follow that the price paid for an investment common

* Corresponding author. Tel: +96279512718

E-mail address: g.aburumman@ju.edu.jo (G. Abu Rumman) 
stock would be determined mainly by the amount of the dividend. When the dividend remains the same if the share price drops, the dividend yield rises. The yield will fall if the stock price rises. As an investor, you are more likely to see the dividend yield quoted than the dividend rate. The initial reason for this makes sense, a company that pays out dividends at a higher percentage of its share price is offering a greater return for its shareholders' investments. The dividend yield tells you the most efficient way to earn a return. Normally, companies with higher dividend yields are underpriced while stocks with lower dividend yields are considered to be overpriced. The earnings yield is the EPS / Price per share. Alternatively, it can also be written as the Net profit of the company/market capitalization of the company. Like in the case of dividend yield, in the case of Earning Yield also a lower value is a sign of overpricing and a higher value is a sign of underpricing, (Investopedia online). Earnings yield is an indication of the payback period of the stock. It shows how much of the price you pay for the stock will be earned back each year. Out of the net profit, a part of the amount is paid as dividends and the balance is transferred to the reserves of the company. While the dividend yield only captures the tangible yield of the company, the Earnings yield also captures the tangible and intangible yield of the company, (Investopedia online). Money managers often compare the earnings yield of a broad market index (such as the S\&P 500) to prevailing interest rates, such as the current 10-year treasury yield. If the earnings yield is less than the rate of the 10-year Treasury yield, stocks may be considered overvalued. If the earnings yield is higher, stocks may be considered undervalued relative to bonds, (Investopedia online). Economic theory suggests that investors in equities should demand an extra risk premium of several percentage points above prevailing risk-free rates (such as rates on Treasury bills) in their earnings yield to compensate them for the higher risk of owning stocks over bonds, (Investopedia online). Earnings yield can be useful when there is concern about the rate of return on investment. For equity investors, however, earning periodic investment income may be secondary to growing their investment values over time. Therefore, investors may refer to value-based investment metrics such as $\mathrm{P} / \mathrm{E}$ ratio more often than earnings yield when making stock investments. An overvalued investment can lower earnings yield and, conversely, an undervalued investment can raise earnings yield. This is because the higher the stock price goes without a comparable rise in earnings, the lower the earnings yield will drop. If the stock price falls, but earnings stay the same or rise, the earnings yield will increase. Value investors seek the latter scenario. The ratio of the dividend yield to earnings yield shows how much of the earnings are directly distributed. A high ratio of DY to EY indicates that the company is distributing a greater chunk of its profits to the shareholders. This is normal in the case of utilities and companies in matured sectors where there is no great scope for expansion of markets or for making acquisitions. In such cases, the company may choose to reward the shareholders through higher dividend yields. A lower ratio of DY to EY is more common among companies that are in the growth stage and will be depending on internal resources to finance their expansion and diversification. That has been the case with IT companies where the earnings run into billions of dollars, but the dividend yields are quite low. In case when the ratio of DY to EY is low then you need to be clear that the company needs to earn a much higher ROE to compensate for the lower dividend payouts (Investopedia online).

Dividends and capital gains are equivalent when an investor considers returns on investment. The only thing that impacts the valuation of a company is its earnings, which is a direct result of the company's investment policy and future prospects (Miller \& Modigliani, 1961). Accordingly, this study investigated the impact of dividends yield and earnings yield based on leverage, as a control variable, on stocks' prices of the industrial Jordanian companies listed on Amman Stock Exchange and investigated this effect in two subsamples by dividing the whole sample into low and high leveraged companies. In this section the study objectives were shown, the study scope was determined, and the study hypotheses were built.

\subsection{Study objectives}

This study aimed at examining the impact of dividends yield and earnings yield based on the leverage ratio, as a control variable, on the stock's price of the industrial listed companies on ASE. Dividend yield enhances the investors' satisfaction, and earnings yield refers to the companies' ability in realizing earnings. These two issues are very important to the companies' continuity and investors' attraction. Therefore, the research problem can be expressed by the following major question:

What is the effect of DY and EY, based on LVRG, on SP?

\subsection{Study scope}

This study examined the impact of dividends yield and earnings yield based on leverage, as a control variable, in the Industrial Jordanian companies listed on ASE for the period (2011-2017). The companies that were selected in the sample had full disclosure for each year. Some companies were removed from the sample because of the non-availability of the data within the study period. As a result, the study sample consisted of 46 industrial Jordanian companies listed on ASE.

The study variables were:

a. stock's price (SP) as a dependent variable

b. dividends yield (DY), and earnings yield (EY) as independent variables

c. leverage ratio (LVRG) as a control variable. 
Depending on the related literature and the purpose of the study the following hypotheses were formed:

$\mathbf{H}_{0 \mathbf{a}}$ : There is no statistically significant impact of dividends yield (DY) and earnings yield (EY) based on leverage (LVRG), as a control variable, on stocks' prices of the industrial Jordanian companies listed on ASE.

$\mathbf{H}_{\mathbf{0}}$ : There is no statistically significant impact of dividends yield (DY) and earnings yield (EY) on stocks' prices of the low leveraged industrial Jordanian companies listed on ASE.

$\mathbf{H}_{\mathbf{0}}$ : There is no statistically significant impact of dividends yield (DY) and earnings yield (EY) on stocks' prices of the high leveraged industrial Jordanian companies listed on ASE.

\section{Theoretical framework and literature review}

\subsection{Theoretical framework}

Dividends and earnings are two important issues in the companies' success and attracting investments. Dividends follow earnings realization. However, this a relationship is not systematically adopted. It is expected that the relationship between earnings and stock's price is positive, while the relationship between dividends and stock's price depends on the risky level accepted by investors. A firm's Profitability is affected by debt financing; this effect may differ from firm to firm, and therefore, differs on its stocks' prices. The following theories investigate the relationship between earnings and dividends from one side and stocks' prices from the other side based on LVRG.

\subsubsection{Dividends Irrelevance Theory}

Miller and Modigliani (1961) concluded that investors do not need to concern themselves with a company's dividends policy since they have the option to sell a portion of their equities' portfolio if they want cash. The theory indicates that a company's declaration and payment of dividends should have no impact on stock's price. If this theory holds true, it will mean that dividends do not add value to a company's stock's price.

\subsection{2 'Bird in the hand' theory of dividends policy}

Essentially, investors are risk-averse and therefore prefer current from future dividends. According to Sealey (1969), shareholders are willing to pay a premium for a stock that offers higher dividend rates compared with others that offer lower dividend rates. Lintner (1962) and Gordon (1963) believe that risk-averse shareholders prefer cash dividend payments rather than future capital gains. Shareholders consider cash dividends to be more certain than future capital gains, thus a "bird in the hand is worth more than two on the bush". Under conditions of uncertainty, investors tend to discount future dividends (capital gains) at a higher rate than they discount current dividends.

\subsubsection{Clientele effect theory}

The demand and goals of investors explain the movement in a company's stock price according to Clientele effect theory. These investors demand come in reaction to a tax, dividend, or other policy changes, which affect the shares' prices. The clientele effect first assumes that specific investors are preliminarily attracted to different company policies and when a company's policy alters, they will adjust their stock holdings accordingly. As a result of this adjustment, stock prices may fluctuate.

\subsubsection{Dividend signaling theory}

An announcement of an increase in dividend payouts is an indication of a positive future prospects according to Dividend signaling theory. This theory is directly tied to a game theory; managers with good investment potential are more likely to signal. Because the dividend signaling theory has been treated skeptically by analysts and investors, there has been regular testing of the theory. Studies indicated that dividend signaling does occur. An increase in a company's dividend payouts generally refer to the positive future performance of the company's stock, while a decrease in dividend payouts tend to accurately portend negative future performance by the company.

\subsubsection{Catering dividend theory}

This theory emphasis meeting the investor dividends requirements and states that company's stock price would increase with the investors' dividend requirements. The management would announce dividends if this transaction increases stock's price (Baker \& Wurgler, 2004). 


\subsubsection{Life cycle theory of dividends}

According to this theory dividend tend to be paid by mature firms, while young ones, generally, face relatively abundant investment opportunities with limited resources, so that retention dominates distribution. In addition, growing firms pay no dividends whereas old and stable firms pay a significant portion of the retained earnings as dividends. It means that the older and stable the firm is, the more it pays dividends (DeAngelo et al., 2006).

\subsubsection{Agency theory}

Agency theory is a principle that is used to explain and resolve issues in the relationship between business principles and their agents. This relationship affects business efficiency. Most commonly, this relationship is the one between shareholders, as principals, and company executives, as agents. An agency, in broad terms, is any relationship between two parties in which one, the agent, represents the other, the principal, in day-to-day transactions. The principal or principals have hired the agent to perform a service on their behalf.

\subsection{Literature review}

The following studies discussed the impact of DY or and EY and other related variables on SP.

Khan et al. (2011) aimed to explain the effect of dividend policy on Stock Prices. The study sample of 55 companies listed on Kuwait Stock Exchange (KSE) -100 Index was selected from 2001 to 2010. Fixed and random effects estimation models were applied on panel data to determine the relationship between dividend policy and stock prices. The study found that Dividends Yield, Earnings per Share, Return on Equity, and Profit after Tax are positively related to stock prices, while Retention Ratio has negative relation with Stock Prices, and significantly explains the variations in the stock market prices. These findings further elaborate dividend policy is important as it provides a signal about the success of the company. Hashemijoo et al. (2012) examined the relationship between dividend policy and share price volatility with a focus on consumer product companies listed on Malaysian stock market. The study sample of 84 companies from 142 consumer product companies listed on the main market of Bursa Malaysia was selected. The relationship between share price volatility with two main measurements of dividend policy, (dividend yield and dividend payout ratio) was examined by applying multiple regression for a period of six years from 2005 to 2010. The study found that there is a significant negative relationship between share price volatility with two main measurements of dividend policy which are dividend yield and dividend payout ratio. Also, the study found that the dividend yield and size have the most impact on share price volatility among predictor variables. Zakaria et al. (2012), examined the impact of dividend policy on the share price volatility of the Malaysian listed construction and material companies using the least square regression method after controlling for debt, firm size, investment growth, and earnings volatility. The study found only 43.43 percent of the changes in the share prices are explained by dividend yield, dividend payout ratio, and investment growth, leverage, and earnings volatility. Dividend yield, investment growth, and earnings volatility insignificantly influence the changes in the company's share prices. Leverage negatively influences the movement of the share price. Al-Shawawreh (2014) examined the relationship between dividend policy and share price volatility. The study sample consists of 53 companies, listed on the main market of ASE, were selected for a period of 13 years from 2001 to 2013. The study found a significant negative relationship between share price volatility with dividend payout ratio, and a very weak positive relationship between dividend yield and share price volatility. Ahmed (2014) investigated the factors which affect the stock prices of the Textile composite sector of Pakistan during the period of 2005 to 2014, The data of 12 textile companies have been used. Advanced econometric techniques were used to see the impact of these variables. The impact of earnings and dividend per share was determined by using the Multiple regression model. The study revealed that dividends per share and earnings per share have a positive and significant impact on stock prices. The study further found a positive relationship between dividends and earnings per share.

Arslan et al. (2014), analyzed the impact of dividend yield and price-earnings ratio on stock returns of non-financial listed firms in Pakistan. The economic behavior of companies has great importance because this behavior influenced the firms' performance. In Pakistan, economic behavior has hardly been explored. The data of 111 non-financial KSE listed firms for a period of 1998 to 2009 have been used. The advanced econometrics techniques were employed for analysis and determining the relationship of these variables. The impact of dividend yield and price-earnings ratio on stock returns was determined by using the fixed effect model. The study found a significant negative relationship between dividend yield and stock prices. Ordu et al. (2014), discussed the effect of dividend payment on the market prices of shares in Nigeria of 17 quoted firms using time series on dividend per share, dividend yield, and dividend payout ratio that ranges between 2000 and 2011. The model specification for the analysis of data is ordinary least squares techniques applied as panel estimation. The dividend payment, dividend per share, dividend yield, dividend payout ratio, and earning per share are significant in explaining the observed differences in share market prices of quoted firms in Nigeria. Sharif et al. (2015) investigated the effect of dividend policy on stock prices. The study analyzed 45 non-financial companies listed on the KSE-100 index that have earned profits and paid dividends for a period of twelve-year 2001-2012, and panel data were pooled and analyzed using Least squares regression, fixed and random effect tests were run. Random effects results were focused on after applying Hausman's test. The study found that Dividend per Share and Retention Ratio have an insignificant relationship 
with Share Market Prices. The dividend Payout Ratio has a significant positive relationship with Share Prices. Earnings per Share have a positive significant relation to Stock Prices, and there is a negative significant relationship between Return on Equity and Share Prices. Aldaas (2017) investigated the effect of cash dividend distributions on market prices of industrial companies listed on ASE. A random sample was selected. The sample consists of (25) industrial companies. Using simple and multiple regression analysis, the study found that the changes in dividends were able to explain more than the changes in net profit of the changes in the dependent variable (stock price). Memon et al. (2017) examined the impact of dividends policy on market prices of firms' stocks of the nonfinancial sectors in Pakistan during the period from 2006 to 2015. Using the outcome of fixed effects Regression model exposed that there is a significant negative impact of dividend yield and significant positive impact of dividends payout ratio on stocks market prices. The results of control variables showed that growth in assets, growth in earnings, growth in sales, and size had a significant positive impact on stock market prices while liquidity, leverage, and profit after tax had no significant impact on stock market prices during the study period. The study found that the outcomes of this research signify that the dividends policy had a significant impact on the market prices of stocks in Pakistan. Bouteska and Regaieg (2017) aimed to examine the relationship between accounting earnings, dividends, stock prices, and stock returns for companies listed at the Tunisian stock exchange, using panel data obtained from the annual reports and financial statements of 57 Tunisian companies over the period 2005-2015. The empirical results indicated a significant value relevance of accounting earnings and dividends reported by Tunisian companies. The findings from the study revealed that shareholders pay special attention to the impact of dividend and dividend yield in their investment decision. Moreover, investors should consider informative earnings numbers as investment criteria as well as many other factors.

Ahmad et al. (2018), aimed to examine the effect of dividend policy on the stock price volatility of firms listed in the Amman Stock Exchange. The data applied for the study consisted of 228 firms listed on the Amman Stock Exchange from the period 2010 to 2016 which made up 1596 firm-year observations. The findings showed that both main variables of dividend policy (dividend yield and dividend payout) have a negative significant relationship with stock price volatility. This implies that the higher the dividend yield and dividend payout of the firms, the lower the stock price volatility which leads to more stability of the stock price. It is suggested that firms in the Amman Stock Exchange should maintain a dividend policy that fits into the existing and prospecting investors. Nguyen, et al. (2019), Taking the initiative of the debatable relationship between dividend policy and share price volatility and addressing the limitation of a statistical model of the previous papers in the context of Vietnam. A sample of 141 listed non-finance companies in the Ho Chi Minh Stock Exchange from 2011 to 2016 was employed. The paper revealed that the dividend yield has a statistically significant negative impact on share price volatility. Hunjra et al. (2020) investigated the stock prices function in the case of Pakistan. The paper used OLS for empirical analysis. The dividend yield is inversely related to stock prices. The volatility in stock prices is one of the most discussed topics in finance. Many studies have been conducted to find the factors which cause fluctuation in stock prices and different results have been found. In this study an attempt has been made to see the effect of dividend yield, dividend payout ratio, return on equity, earning per share, and profit after tax on stock prices in Pakistan. For this purpose, four non-financial sectors (Sugar, Chemical, Food and personal care, Energy) have been selected. A sample of 63 companies listed at the Karachi stock exchange was analyzed for the period of 2006-2011. The ordinary least square regression model has been applied to panel data. The results indicated dividend yield and dividend payout ratio which are both measures of dividend policy have a significant impact on the stock price. The dividend yield is negatively related to stock price and the dividend payout ratio is positively related to stock price, which means that these results are against dividend irrelevance theory. Others examined the continual impact of profitability indicators on stock market prices of listed industrial companies in Jordan, during the period from 2012 to 2016. The analysis showed that investors in ASE were affected by EY in two Years, the year of earnings realization, and the following year, while they are affected by DY in the following three years of earnings realization.

\section{Methodology}

This section includes population, sample, and data collection. It defines the variables, designs the study model, and discusses the research methodology.

\subsection{Population, Sample, and Data Collection}

The study population consists of all the industrial publicly held Jordanian companies listed on ASE for the period 20112017. The study sample includes (46) companies in which the required data are available within the study period. The data industrial sector sample was collected from the company guide of ASE, annual financial statements, and publications (financial position, financial ratios, and relevant information) which relate to the study topic were used. Moreover, other secondary data were collected from books, the internet, and previous articles.

\subsection{Variables Definitions}

This study investigated the impact of dividends yield and earnings yield on the industrial firms' stocks' prices based on LVRG, as a control variable, in ASE. Therefore, the study variables are as follows: 


\subsubsection{Dependent Variable}

Stock price: Is the price of one share in several salable shares of a company or derivative or other financial assets. Therefore, it can be said that the share price is the highest amount a person wants to receive for selling the stock, or the lowest amount that it can be bought for. In this study, it is the closing price of the company's stock on the closing trading date in a specific year (Iqbal, et al., 2016).

\subsubsection{Independent Variables}

The study's independent variables are dividends yield and earnings yield.

\subsubsection{Dividends Yield}

This is the yearly dividend per share, divided by the closing price per share. It is also the company's total annual dividend payments divided by its market capitalization, assuming that number of shares is constant. It is often expressed as a percentage. This ratio shows the return that stockholders obtain for their investments in the company by declaring dividends. The dividend yield is quoted as a percentage rather than a dollar amount. Dividend yield could be expressed by the following equation:

$$
D Y_{i t}=\frac{d i v_{i t}}{S P_{i t}}
$$

where: $D Y_{i t}$ is the dividends yield for $i^{\text {th }}$ cross-sectional company during year $t$

$d i v_{i t}$ represent the dividend per share for $i^{\text {th }}$ cross-sectional company during year $t$

$S P_{i t}$ represents the stock price for $i^{\text {th }}$ cross-sectional company during year $t$.

\subsubsection{Earnings Yield}

This is the yearly earnings per share divided by the closing stock's price at the end of the year. It shows the percentage of each monetary unit invested in the shares acquired by the company. The related literature found a positive relationship between earnings yield and stock price. Earnings yield could be expressed by the following equation:

$$
E Y_{i t}=\frac{E P S_{i t}}{S P_{i t}}
$$

where: $E Y_{i t}$ is the Earnings Yield for $i^{\text {th }}$ cross-sectional company during year $t$

$E P S_{i t}$ : represents the Earning Per Share for $i^{t h}$ cross-sectional company during year $t$

\subsubsection{Control Variable}

Leverage ratio: evaluates a company's debt levels with respect to total assets or equity. In this study, total assets will be used as a base to calculate LVRG ratio. The sample will be split into two groups of leverage level depending on the median of leverage ratio which equals to 0.31 . If the LVRG ratio is $\leq 0.31$ the company will get 0 value, and considered to be low leveraged firm, but if leverage ratio is $>0.31$ the company is considered as a high leveraged firm and is given a value of 1 . Leverage ratio could be expressed by the following equation:

$$
L V R G_{i t}=\frac{T D_{i t}}{T A_{i t}}
$$

where: $L V R G_{i t}$ is the Leverage ratio for $i^{t h}$ cross-sectional company during year $t$

$T D_{i t}$ : represents the Total Debt "Total Liabilities" for $i^{\text {th }}$ cross sectional company during year $t$

$T A_{i t}$ : represents the Total Assets for $i^{\text {th }}$ cross-sectional company during year $t$.

\subsection{Research Methodology}

To examine the study hypotheses as stated previously, an aggregation of panel data was constructed from the financial data posted in ASE. In considering the dividends yield and earnings yield, it was noticed that many firms incurred losses in some years so, they were not being able to distribute dividends, and even those who pay dividends they did not continuously do 
so. Panel data methodology has been used to examine the impact of earnings yield and dividends yield on stock's price using LVRG as a control variable. To test the study hypotheses multiple regression analyses were run, the following multiple regression model was built first for the whole sample and then for the two subsamples, (low and high leveraged companies):

$$
S P_{i t}=\beta_{0}+\beta_{1} D Y_{i t}+\beta_{3} E Y_{i t}+\beta_{2} L V R G_{i t}+\mu t
$$

where: $\mu t$ : represent the Residual error in the equation.

\subsection{The study model}

Fig. 1 shows the structure of the proposed study of this paper.

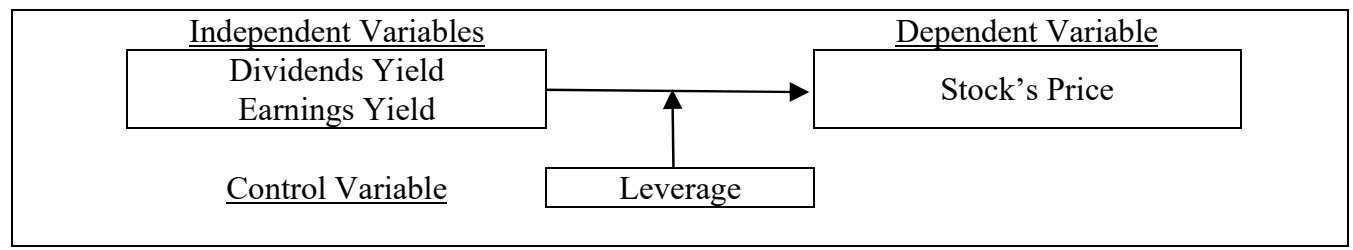

Fig. The proposed study

\section{Results and Discussions}

\subsection{Descriptive Statistics}

The study variables' descriptive statistics (mean, median, standard deviation, variance, minimum, and maximum) are shown in Table 1. The average stock's price for the whole industrial sector listed companies during the seven-year study period (2011-2017) is 2.54, which means that on average the stock's price equals more than two and half times of the stock par value. The SP median is 1.48 , which means that the number of industrial companies above the mean is lower than the number of industrial companies below the mean. The stock's price standard deviation is 4.80 , which refers to the differences between stocks' prices. The highest value of stock's price is 46.51 and the lowest value is 0.13 during the study period. This huge gap between the highest and lowest value of a stock's price explains the high standard deviation result.

Table 1

Variables Descriptive Statistic

\begin{tabular}{lllll}
\hline & SP & DY & EY & LVRG \\
\hline Mean & 2.54 & 0.03 & -0.01 & 0.34 \\
Median & 1.48 & 0 & 0.04 & 0.31 \\
Std. Deviation & 4.8 & 0.03 & 0.16 & 0.2 \\
Variance & 23.03 & 0.01 & 0.03 & 0.04 \\
Minimum & 0.13 & 0 & -0.83 & 0 \\
Maximum & 46.51 & 0.15 & 0.58 & 1.2 \\
\hline
\end{tabular}

The mean value of dividends yield is 0.03 , which seems to be a low shareholders' return on their investments. The standard deviation is 0.03 , this result indicates similar companies distributed dividends. The highest dividends yield is 0.15 and the lowest shows no dividends distribution. The mean value of earnings yield is -0.01 . This result shows that on average industrial Jordanian companies realized losses within the study period, 2011 to 2017, with a standard deviation of 0.16 , which indicates some similarity in the industrial companies' earnings. The EY median is 0.04 , which means that the number of industrial companies above the mean is higher than the number of industrial companies below the mean. The highest earnings yield is 0.58 and the lowest is -0.83 . The mean value of leverage ratio is 0.34 , which means that on average the industrial Jordanian companies' total debt equals about one-third of their total assets, with a standard deviation of 0.20 . The highest leverage ratio is 1.20 , this ratio means that total debt is higher than total assets, and may be abnormal, which refers to a very bad financial position of a company. The lowest leverage ratio is 0.00 indicating no debt for the company.

\subsection{Correlation Matrix}

Table 2 shows the study variables correlation coefficients matrix for the dependent and independent variables. Table 2 shows a statistically significant positive relationship between each dividend yield and earnings yield $(0.42,0.38$ respectively) with stock's price, which means that an increase in dividends yield and/or earnings yield will increase stock's price. Table 2 also, shows a statistically significant negative relationship between leverage with each of stock's price, dividend yield, and earnings yield. This means that an increase in leverage ratio will result in a decrease in each stock's price, dividends yield, and earnings yield. This result shows that leverage represents the load on the company's resources. The relationship coefficient between DY and EY is 0.55 which is statistically significant. This means that an increase in EY will result in an increase in DY. 
Table 2

Study Variables Spearman Correlation Coefficients

\begin{tabular}{lllll}
\hline & SP & DY & EY & LVRG \\
\hline SP & 1.00 & & & \\
DY & $0.42^{*}$ & 1.00 & 1.00 & 1.00 \\
EY & $0.38^{*}$ & $0.55^{*}$ & $-0.21^{*}$ & \\
LVRG & $-0.23^{*}$ & $-0.38^{*}$ & C & \\
\hline
\end{tabular}

\subsection{Regression Analysis}

This section provides the regression results of the panel data analysis. The results show the impact of DY and EY based on LVRG, as a control variable, on SP for the whole sample, the low leveraged sample companies, and the high leveraged sample companies.

\subsubsection{The effect of DY and EY, with LVRG as a control variable, on SP for the whole sample}

Table 3 shows the regression results for the whole sample with DY and EY as independent variables and SP as a dependent variable, treating LVRG as a control variable. The results show that $\mathrm{F}$ value is significant at $1 \%$ level which indicates that the model is appropriate and statistically significant to analyze the effects of DY and EY, based on LVRG as a control variable, on SP. The $t$ values of the effects of DY and EY on SP are insignificant at the 5\% significance level. This result might be different from results of previous studies such as (Khan et al., 2011; Zuriawati Zakaria et al., 2012) because of different environments and/or periods.

Table 3

The effects of DY and EY with LVRG, as a control variable, on SP for the whole sample

\begin{tabular}{lllll}
\hline variables & Coefficients & Std. Err. & $t$ value & \\
\hline Constant & 1.78 & 0.64 & 2.78 & P value \\
DY & -0.01 & 0.06 & -0.21 & 0.00 \\
EY & 1.37 & 1.08 & 1.28 & 0.83 \\
LVRG & 2.39 & 1.75 & 1.36 & 0.20 \\
F value & & & & 0.17 \\
\multicolumn{1}{c}{ Adjusted $R^{2}$} & 0.014 & & & \\
\hline
\end{tabular}

The adjusted $R^{2}(0.014)$ in Table 3 shows that the variation in DY and EY, with the control variable LVRG, interprets $1.4 \%$ of the variation in SP. Based on these results the first null hypothesis is accepted, which means that DY and EY, based on LVRG as a control variable, does not affect SP at 5\% significant level in the Jordanian industrial firms.

\subsubsection{Leverage level}

In this section, the sample companies were split, based on the leverage ratio, into two equal groups:

a. low leveraged companies, defined as each company that had leverage ratio less than the median $(0.31)$ gets 0 value.

b. high leveraged companies, defined as each company that had leverage ratio equal or more than the median $(0.31)$ gets a value of 1 .

The regression results for the low leveraged companies in Table 4, show insignificant effects of DY and EY, with LVRG as a control variable, on SP. This insignificant result may be caused by the low level of out financing, as an additional control side. F value is significant at the 5\% significance level, which means that this model is appropriate to analyze the impact of DY and EY on SP, based on LVRG as a control variable,

\section{Table 4}

The effects of DY and EY with LVRG, as a control variable, on SP for the low-leveraged companies

\begin{tabular}{lcccc}
\hline Variables & Coefficients & Std. Err. & $t$ value & P value \\
\hline Constant & 3.75 & 1.27 & 2.95 & 1.35 \\
DY & 0.19 & 0.14 & 0.00 \\
EY & 4.44 & 3.69 & -1.20 & 0.18 \\
LVRG & -8.91 & 5.29 & 0.03 & 0.10 \\
F value & & & & \\
\multicolumn{1}{c}{$R^{2}$} & 0.065 & & & \\
\hline
\end{tabular}

The low leveraged group coefficient of determination is 0.065 , which means that the change in DY and EY, with LVRG as a control variable, in the low leveraged companies, interprets $6.5 \%$ of the variation in SP. Based on these results the second null hypothesis is accepted, which means that DY and EY, with LVRG as a control variable, in the low leveraged companies 
of the Jordanian industrial firms does not affect SP at 5\% significance level. F value of the high leveraged Jordanian industrial companies' regression analysis, in Table 5, is significant at the $1 \%$ significance level, which means that this model is appropriate to analyze the impact of DY and EY, with LVRG as a control variable, on SP. The regression results, in table 5.2.2, of the high leveraged Jordanian industrial companies, show a positive significant effect of DY ( $\mathrm{t}$ value 4.08 is significant at the $1 \%$ significance level) on SP, and an insignificant effect of EY on SP.

Table 5

The effect of DY and EY with LVRG, as a control variable, on SP for the high-leveraged companies

\begin{tabular}{|c|c|c|c|c|}
\hline Variables & Coefficients & Std. Err. & $t$ value & P value \\
\hline Constant & 3.83 & 1.03 & 3.71 & 0.00 \\
\hline DY & 0.51 & 0.13 & 4.08 & 0.00 \\
\hline EY & 0.02 & 1.92 & 0.01 & 0.99 \\
\hline LVRG & -2.54 & 2.01 & -2.54 & 0.01 \\
\hline F value & & & & 0.00 \\
\hline$R^{2}$ & 0.163 & & & \\
\hline
\end{tabular}

The high leveraged group coefficient of determination is 0.163 , which means that the change in DY and EY with LVRG, as a control variable, in the high leveraged Jordanian industrial companies, interprets $16.3 \%$ of the variation in SP. The coefficient of determination increases to $16.3 \%$ in the high leveraged group, from $1.4 \%$ in the whole sample. It seems that the high leverage level, which refers to additional control from creditors, improves the interpretation ability of the changes in DY and EY with LVRG, as a control variable, in explaining the changes in SP. Based on the regression results the third alternative hypothesis is accepted for DY, which means that DY affects positively SP at the $1 \%$ significance level. However, the null hypothesis is accepted for EY, which means that EY does not affect SP at the 5\% significance level.

\section{Conclusions}

This study investigates the impact of dividends yield and earnings yield, based on LVRG as a control variable, on the stock's price of the Jordanian Industrial listed companies in (ASE) using panel data analysis techniques for the period from 20112017. The multiple regression results of this study supported the first and the second null hypotheses that there is no statistically significant impact of dividend yield and earnings yield, based on LVRG as a control variable, on stock's price in the whole sample and low leveraged Jordanian industrial companies. However, the results for the high leveraged Jordanian industrial companies showed that there is a statistically significant impact of dividend yield, based on LVRG as a control variable, on stock's price. This result may indicate that creditors add additional control. The EY, based on LVRG as a control variable, does not have a significant impact on stock's price at 5\% significance level in the high leveraged Jordanian industrial companies. The coefficient of determination increases for the high leveraged company's model.

\section{References}

Ahmed, I. (2018). Impact Of Dividend Per Share and Earnings Per Share On Stock Prices: A Case Study From Pakistan (Textile Sector). IJSSHE-International Journal of Social Sciences, Humanities and Education Volume, 2(2).

Ahmad, M. A., Alrjoub, A. M. S., \& Alrabba, H. M. (2018). The effect of dividend policy on stock price volatility: empirical evidence from amman stock exchange. Academy of Accounting and Financial Studies Journal, 22(2), 1-8.

Aldaas, A. (2017). The effect of cash dividends on the market share price of industrial companies listed at Amman stock exchange. Global Journal of Business and Management, 5, 204-12.

Arslan, M., Zaman, R., \& Phil, M. (2014). Impact of dividend yield and price earnings ratio on stock returns: A study nonfinancial listed firms of Pakistan. Research Journal of Finance and Accounting, 5(19), 68-74.

Ang, J. S., \& Ciccone, S. J. (2011). Dividend irrelevance theory. In Dividends and Dividend Policy.

Al-Shawawreh, F. K. (2014). The Impact of Dividend Policy on Share Price Volatility: Empirical Evidence from Jordanian Stock Market. European Journal of Business and Management, 6, 133-43.

Baker, M., \& Wurgler, J. (2004). A catering theory of dividends. The Journal of Finance, 59(3), 1125-1165.

Bouteska, A. Regaieg, B. (2017). The Association between Accounting Earnings, Dividends, Stock Prices, and Stock Returns: Value Relevance of Accounting Standards in the Tunisian Stock Market. International Journal of Accounting and Financial Reporting, 7(1), 171-189.

DeAngelo, H., DeAngelo, L., \& Stulz, R. M. (2006). Dividend policy and the earned/contributed capital mix: a test of the life-cycle theory. Journal of Financial Economics, 81(2), 227-254.

Gordon, M. J. (1963). Optimal investment and financing policy. The Journal of Finance, 18, $264-72$.

Graham, B., \& Dodd, D. L. (1951). Security Analysis, $3^{\text {rd }}$ ed., New York.

Miller, M. H., \& Modigliani, F. (1961). Dividend policy, growth, and the valuation of shares. the Journal of Business, 34(4), 411-433.

Nguyen, D. T., Bui, M. H., \& Do, D. H. (2019). The relationship of dividend policy and share price volatility: A case in Vietnam. Annals of Economics \& Finance, 20(1). 
Hashemijoo, M., Mahdavi Ardekani, A., \& Younesi, N. (2012). The impact of dividend policy on share price volatility in the Malaysian stock market. Journal of Business Studies Quarterly, 4(1).

Hunjra, A. I., Ijaz, M., Chani, D., Irfan, M., \& Mustafa, U. (2014). Impact of dividend policy, earning per share, return on equity, profit after tax on stock prices. International Journal of Economics and Empirical Research, 2(3), $109-115$.

Iqbal, S., Abbas, F., \& Aziz, B. (2016). Impact of Dividend Policy on Stock Prices: Evidence from Pakistan. IBA Business Review, 11(2).

Khan, K. I., Aamir, M., Qayyum, A., Nasir, A., \& Khan, M. I. (2011). Can dividend decisions affect the stock prices: A case of dividend paying companies of KSE. International Research Journal of Finance and Economics, 76(68), 69-74.

Lintner, J. (1962) Dividends, Earnings, Leverage, Stock Prices and the Supply of Capital to Corporations. The Review of Economics and Statistics, 44, 243-269.

Memon, N. A., Channa, N., \& Khoso, I. (2017). Impact of dividend policy on market prices of shares: Evidence from Pakistan. Journal of Business Strategies, 11(2), 57-72.

Ordu, M. M., Enekwe, C. I., \& Anyanwaokoro, M. (2014). Effect of dividend payment on the market price of shares: A study of quoted firms in Nigeria. IOSR Journal of Economics and Finance, 5(4), 49-62.

Sealey, J. E., Kirshman, J. D., \& Laragh, J. H. (1969). Natriuretic activity in plasma and urine of salt-loaded man and sheep. The Journal of Clinical Investigation, 48(12), 2210-2224.

Sharif, I., Adnan, A. L. İ., \& Jan, F. A. (2015). Effect of dividend policy on stock prices. Business \& Management Studies: An International Journal, 3(1), 56-87.

Zakaria, Z., Muhammad, J., \& Zulkifli, A. H. (2012). The impact of dividend policy on the share price volatility: Malaysian construction and material companies. International Journal of Economics and Management Sciences, 2(5), 1-8.

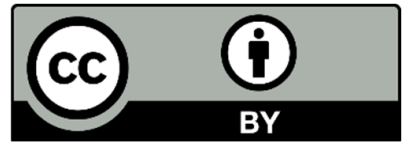

(C) 2022 by the authors; licensee Growing Science, Canada. This is an open access article distributed under the terms and conditions of the Creative Commons Attribution (CC-BY) license (http://creativecommons.org/licenses/by/4.0/). 